\title{
Editorial on the special issue "Rethinking Migration in Times of Economic Crisis in Europe"
}

\author{
Felicitas Hillmann, Anne v. Oswald, Andrea Schmelz
}

The CPoS special issue presented here is the result of a two-day international conference entitled "Rethinking Migration in Times of Economic Crisis in Europe", which was outlined by the coordinators of this issue and held at the Haus der Kulturen der Welt in Berlin in December 2010. Starting point was the question, to what extent the at that point subsiding economic crisis impacted upon the employment of migrants? Could an interrelationship between the economic- and financial crisis and the employment situation of migrants even be established? And were there any comparable historical precedents or perhaps regional examples for dealing with such crisis situations?

In the years 2009 and 2010, international organisations such as the OECD, ILO or the World Bank noted in their reports that the economic crisis affects the most vulnerable population groups in particular, to which one can also count migrants and refugees solely because of their different legal status. In the autumn of 2010, the Migration Policy Institute stated that

- two years after the crisis, both legal and illegal immigration into EU countries had slowed down considerably,

- in various countries, certain immigrant groups were predominantly confronted with the effects of the crisis on the labour market (e.g. in Spain, the North African immigrants and the Latin American migrants; in Great Britain, the immigrants from Bangladesh and India),

- furthermore, men - especially young men - were more strongly affected by the crisis-ridden developments than women, because they were generally employed in more crisis-prone sectors, such as construction or certain industries that are highly susceptible to changes in the economy,

- remittances by migrants to their countries of origin declined significantly. The recipient countries were thus particularly affected by the indirect effects of the crisis.

The annual OECD report on the development of immigration and emigration ("Migration Outlook") also informed about the growing difficulties of the foreign population on the labour markets of industrialised countries. According to this report, the labour market integration of migrants experienced a particularly strong deceleration in those countries which had been most severely affected by earlier recessions (USA, Britain, Ireland and Spain): As a consequence, unemployment rose 
faster among the migrant population than among the native population, as the migrants were more strongly represented in cyclical industries, especially in manufacturing and construction. Furthermore, migrants were under higher risk to become unemployed, as they are generally more likely to work under temporary contracts, on average have a lower level of education and are more commonly employed in small and cyclically vulnerable companies.

Furthermore, the OECD report pointed out the higher risks for self-employed migrants: They frequently have less financial reserves than the native entrepreneurs and thus can hardly compensate economic crises under their own power. As another reason for the decreasing presence of migrants in the labour market, the report also contemplated discrimination. It becomes apparent that, in order to grasp the complexity of migration in times of economic crisis, an isolated observation of jobrelated migration is not sufficient. Especially in times of crisis, possible connections between the various forms of migration are utilised, as for example through applications for and granting of visas or through circular migration. Focusing solely on the changes within one form of migration would be insufficient, because usually different forms of migration develop in relation to each other and are related to other subfields of action. To give an example: If, due to crisis-indicating developments in a country, no more visas are being granted for certain segments of the labour market, it may happen that the number of family reunifications increases. So, we argue that the understanding of migration is in need of a comprehensive and methodologically open approach.

The articles presented in this special issue approach this complex topic from different methodological perspectives. While the contributions of Christiane Kuptsch as well as Dirk Godenau (in collaboration with Dita Vogel, Vesela Kovacheva and $Y a n(W u)$ attempt an analysis of the status quo based on available quantitative data, the case studies by Irial Glynn and Piotr Plewa present a historical comparison of the economic crises of 2008 as well as 2009 with the crisis in the 1930s and the so-called oil crisis in 1973/74. Two further contributions of Dirk Hoerder and Marketa Rulikova refer to migration as individual strategies and to the significance of transnationalism. These studies have primarily applied qualitative methods and only cursorily use quantitative data.

Christiane Kuptsch's piece deals with the crisis-related labour market policy for migrants in Europe from a macroeconomic perspective. On the basis of available EU-statistics, the author shows how much the economic crisis has slowed down worldwide economic growth and how these changes have considerably affected sectors with particularly high employment of migrants. The impact of the economic crisis can be clearly proven. Christiane Kuptsch inquires about the differences and similarities of the various national migration policies with a focus on six case countries (Ireland, Spain, United Kingdom, Italy, France and Czech Republic) and distinguishes the data according to the options "return, onward migration or permanent settlement". These are implemented in the form of existing regulations, adaptations of existing regulations or new regulations within the migration policies of the respective countries. Kuptsch shows very clearly that, due to existing bilateral or multilateral agreements, an immediate action is not readily possible in most 
countries and how different short- and long-term measures are designed. Some countries have seized the "opportunity" of the crisis by implementing long-planned re-regulations. The author further emphasizes how these countries, as actors in migration policy, have acted more strongly in favour of migrants during the crisis and have thus actively pursued the structures of future labour market policy.

The contribution of Dirk Godenau in cooperation with Dita Vogel, Vesela Kovacheva and Yan Wu places its analytical focus on the comparison between Spain and Germany. The authors have thus chosen two contrasting examples of the impact of the global crisis on national labour markets and on migrants. Here, the two structural features sector (according to NACE ${ }^{1}$-classification) and economic growth are connected to immigration processes. At the same time, the public discourse on immigration is examined. By comparing the chosen economies, this article illustrates how much the global crisis is regulated by the national organisation of the labour market and by the access of migrants to labour markets. Even more so, it shows how strongly, in the context of the economic crisis, the public discourse is drawn to the issue of "migration" and how this discourse runs almost independently from economic development.

The two historical articles of Irial G/ynn and Piotr Plewa attempt a comparison between the economic crisis 2008/09, the Great Depression in the 1930s (G/ynn), the oil crisis in the early 1970s (G/ynn/Plewa) and the financial crisis in the early 1980s (G/ynn). Methodologically, historical comparisons can be delicate. They do, however, bring with them the added value of a sharp reflection on how to deal with migrants and refugees in times of crisis. In his comparison, Glynn analyses the influence of intergovernmental organisations in nation states and their approach in dealing with refugees in times of economic recession and depression: What influence did the League of Nations during the Great Depression in the 1930s have on national politics and policies regarding Jewish refugees? And, in comparison to the League of Nations, what scope of action did the European Commission have in regard to refugee and migration policy? The author compares the crisis in 1973/74, in the early 1980 s and in 2008/09. G/ynn concludes that despite increasing power of the European Commission towards the individual EU countries, the safety issue concerning migration of the "unwanted" stands in the foreground, and other possible scopes of actions are not used. When dealing with migrants, "More Power, Less Sympathy" is the central approach, which Irial Glynn investigates regarding the European Commission in comparison to the League of Nations.

With the onset of the economic crisis 2008/09, Spain introduced return programmes for migrants. The contribution of Plewa concentrates on this aspect of the correlation between economic crisis and migration and compares voluntary return programmes with similar programmes implemented by other European countries in the 1970s and 1980s. Financial incentives, which were aimed at encouraging migrants to return to their home country, have been trialled in France, Germany, the

1 Nomenclature Générale des Activités Economiques dans I'Union Européene (Classification of the Economic Activities in the European Community). 
Netherlands and Belgium since the oil crisis in 1973/74. Among these, France has developed the most elaborate set of regulations. Plewa compiles existing knowledge about the effects of these repatriation programmes by calling on statistical reports and by interviewing NGOs operating in this field. Generally, financial incentives were given or return tickets were paid for. Drawing on these experiences, Spain developed repatriation programmes, which were either aimed at unemployed migrants, followed a humanitarian approach or offered opportunities for investments in the home country. Plewa is interested in the logic behind the migrants' decisions to return to their home country or to remain in Spain. He sums up that many migrants were still better provided for in Spain than in their country of origin and that many even accepted precarious work conditions. The return options of the migrants differed greatly depending on the country of origin: For instance, in the face of emerging unrest back in their home countries, migrants from North Africa were hardly interested in a return, although they formed the majority of unemployed migrants. Overall, the expectations of politicians regarding the positive effects of these programmes do not seem to have been fulfilled, which the author ascribes to the persistence generated by the general structure of the labour market. This in turn shows the close relationship between labour market and migration policies and thus the difficulty of political intervention without creating unwanted "side effects".

The article of Dirk Hoeder seizes this perspective on the analysis of migration processes - namely the close relationship between migration and other areas of social regulation - and investigates the historical embeddedness of migration processes. From his point of view, it is scientifically less relevant that migrants themselves feel uprooted. Instead, attributions and ideologies, which accompany the migration processes, are rather in the focus of his research interest. Hoerder pointedly looks at historical events, such as the oil crisis in 1973/74 or the crisis in 2008/09, and describes them as events produced by the elites. Hoerder criticises that, historically, mass migrations have not been adequately placed in the context of prevailing ideologies. As a consequence, there are tendencies to underestimate the effects of the 2008/09-crisis on migrants. He attributes this to the strong national fixation of migration research and argues that from the migrant's point of view, relocation essentially takes place between two places and not between two states. Therefore, Hoerder is interested in the transcultural dimension of migration and in the existing global inequalities, which is being expressed through agency and through the ideological construction of "others". Here, Hoerder argues not only as a historian, he also cautions citizens to look more closely and recommends a stronger political interpretation of global mass migration.

Marketa Rulikova directs her attention more on the individual situation of migrants in the context of the crisis. Based on a case study of the Czech Republic, Rulikova investigates the effects of the economic crisis in 2008/09 on labour migrants, both on the policy-level and on the level of coping strategies of migrants. The Czech Republic itself is a new country of immigration within the EU, which - unlike most European immigration countries - has only recently started to gather experience in international migration and integration policy. In times of economic crisis, the Czech 
Republic actually resorts to the "classical" approach of return programmes, as it had already been practised in Germany or Spain in the 1970s and 1980s (see also Plewa). Rulikova analyses to what extent the return programme was taken advantage of by migrants. In addition, she presents the results of an ethnographic study, which deals with the different reactions to the economic crisis of migrant workers from the Vietnamese, Ukrainian and Mongolian migrant communities in Prague. It is not surprising that the limited material benefits of the official return programme in the Czech Republic were only claimed by a small number of migrants. During the crisis, unemployed migrants preferred to stay within their respective communities or take on irregular work contracts, rather than returning to their poverty-stricken countries of origin. Rulikova exposes the individually complex reasons for remaining in the Czech Republic, despite difficult living conditions, and thus places agency of migrants at the centre of her analysis.

All in all, the various analyses and case studies presented in this special issue show, that crisis-induced short-term policy responses aimed at averting immigration as well as repatriation programmes can only partially influence the mediumand long-term structural need of migrants.

Instead, crises create new migration dynamics and adaptation strategies of migrants. Looking at it from a migrant point of view, economic crises oftentimes mean a further deterioration of the already difficult living conditions. As far as the political situation allows it, migrants are seeking ways to change their circumstances, again and again even accepting high personal risks. However, on a national level, many countries react to the economic crisis by further specifying existing policies or by reducing visa issues for various labour market segments. The articles presented in this issue show that, so far, there are yet no joint "European" solutions for dealing with the effects of the economic crisis, but rather a number of differing national strategies.

\section{References}

IOM 2009: The Impact of the Global Economic Crisis on Migrants and Migration. In: IOM Policy Brief March 2009. Geneva

Papademetriou, Demetrios et al. 2010: Migration and Immigrants Two Years after the Financial Collapse: Where Do We Stand? Washington: The migration policy Institute.

OECD 2009: Policy Brief: International Migration: Charting a Couse through the Crisis. Ort: OECD Observer.

Sommerville, Will; Sumption, Madeleine 2010: Immigration in the United Kingdom. The recession and beyond. Equality and Human Rights Commission. Washington DC: Migration Policy Institute. 
Prof. Dr. Felicitas Hillmann ( $₫)$. FU Berlin, Institut für Geographische Wissenschaften, ZELF, Malteserstr. 74 - 100, 12249 Berlin. E-Mail: hillmann@zedat.fu-berlin.de,

URL: http://www.geo.fu-berlin.de/geog/fachrichtungen/anthrogeog/zelf/Mitarbeiterlnnen/ Hillmann

Dr. Anne von Oswald. Netzwerk Migration in Europa e.V., Limonenstr. 24, 12203 Berlin. E-Mail: oswald@network-migration.org, URL: www.network-migration.org

Dr. Andrea Schmelz. Netzwerk Migration in Europa e.V., Limonenstr. 24, 12203 Berlin. E-Mail: schmelz@network-migration.org, URL: www.network-migration.org 


\section{Comparative Population Studies - Zeitschrift für Bevölkerungswissenschaft}

wWw.comparativepopulationstudies.de

ISSN: 1869-8980 (Print) - 1869-8999 (Internet)

Published by / Herausgegeben von

Prof. Dr. Norbert F. Schneider

Federal Institute for Population Research

D-65180 Wiesbaden / Germany

Managing Editor /

Verantwortlicher Redakteur

Frank Swiaczny

Editorial Assistant /

Redaktionsassistenz

Katrin Schiefer

Language \& Copy Editor (English) /

Lektorat \& Übersetzungen (englisch)

Amelie Franke

Copy Editor (German) /

Lektorat (deutsch)

Dr. Evelyn Grünheid

\section{Layout / Satz}

Beatriz Feiler-Fuchs

E-mail: cpos@destatis.de

\author{
Scientific Advisory Board / \\ Wissenschaftlicher Beirat \\ Jürgen Dorbritz (Wiesbaden) \\ Paul Gans (Mannheim) \\ Johannes Huinink (Bremen) \\ Marc Luy (Wien) \\ Clara H. Mulder (Groningen) \\ Notburga Ott (Bochum) \\ Peter Preisendörfer (Mainz)
}

\section{Board of Reviewers / Gutachterbeirat} Martin Abraham (Erlangen) Laura Bernardi (Lausanne) Hansjörg Bucher (Bonn) Claudia Diehl (Göttingen) Andreas Diekmann (Zürich) Gabriele Doblhammer-Reiter (Rostock) Henriette Engelhardt-Wölfler (Bamberg) E.-Jürgen Flöthmann (Bielefeld) Alexia Fürnkranz-Prskawetz (Wien) Beat Fux (Zürich) Joshua Goldstein (Rostock) Karsten Hank (Köln) Sonja Haug (Regensburg) Franz-Josef Kemper (Berlin) Michaela Kreyenfeld (Rostock) Aart C. Liefbroer (Den Haag) Kurt Lüscher (Konstanz) Dimiter Philipov (Wien) Tomáš Sobotka (Wien) Heike Trappe (Rostock) 